\title{
PENALARAN DEDUKTIF SISWA SMP DALAM MENYELESAIKAN MASALAH GEOMETRI BERDASARKAN PERBEDAAN GENDER
}

\author{
Ahmad Afandi \\ IKIP PGRI JEMBER \\ Email:a_afandi41@yahoo.com
}

\begin{abstract}
Abstrak. Penelitian ini bertujuan untuk mendeskripsikan penalaran deduktif siswa SMP dalam menyelesaikan masalah geometri berdasarkan perbedaan gender. Penalaran deduktif pada penelitian ini mengacu pada pernyataan umum, pernyataan khusus, dan melakukan penarikan kesimpulan. Subjek penelitian ini terdiri dari 2 siswa kelas VIII SMP. Teknik pengumpulan datanya dilakukan dengan pemberian tugas dan wawancara.

Data hasil penelitian yang diperoleh sebagai berikut: (1) penalaran deduktif siswa lakilaki. Pada langkah merencanakan penyelesaian masalah; subjek dapat merumuskan pernyataan umum dengan menyebutkan pernyataanyang digunakan untuk menjawaban soal yang diberikan, subjek dapat merumuskan pernyataan khusus dengan menyebutkan pernyataan logis yang mengacu pada pernyataan umum berdasarkan soal yang diberikan, dan subjek dapat melakukan penarikan kesimpulan dengan menetapkan strategi untuk menjawab soal yang diberikan. Pada langkah melaksanakan rencana penyelesaian masalah; subjek dapat merumuskan pernyataan umum dengan menggunakan pernyataan yang digunakan untuk menjawab soal yang diberikan, subjek dapat merumuskan pernyataan khusus dengan menetapkan pernyataan logis yang mengacu pada pernyataan umum berdasarkan soal yang diberikan, dan subjek dapat melakukan penarikan kesimpulan dengan menggunakan premispremis (pernyataan umum dan khusus) yang telah terbukti kebenarannya. (2) penalaran deduktif siswa perempuan. Pada langkah merencanakan penyelesaian masalah; subjek dapat merumuskan pernyataan umum dengan menyebutkan pernyataan yang digunakan untuk menjawaban soal yang diberikan, subjek juga dapat merumuskan pernyataan khusus dengan menyebutkan pernyataan logis yang mengacu pada pernyataan umum berdasarkan soal yang diberikan, dan subjek dapat melakukan penarikan kesimpulan dengan menetapkan strategi untuk menjawab soal yang diberikan. Pada langkah melaksanakan rencana penyelesaian masalah; subjek dapat merumuskan pernyataan umum dengan menggunakan pernyataan yang digunakan untuk menjawab soal yang diberikan, subjek tidak dapat merumuskan pernyataan khusus, dan subjek dalam melakukan penarikan kesimpulan tidak sesuai dengan strategi yang telah ditetapkan pada langkah merencanakan penyelesaian masalah.
\end{abstract}

Kata kunci: Penalaran Deduktif,Penyelesaian Masalah Geometri, Perbedaan Gender. 
Abstract. This study is aimed to describe deductive reasoning e of Junior High School Students in solving geometry problem based on gender difference. Deductive reasoning in this study refers to general premise, specific premise, conclusion drawing. The subjects of this study are two Junior High School Students. The technique of collecting data applied in this study are task giving and interview.

The result of the study would be presented as follows: (1) deductive reasoning e of the male student; at the planning phase for solving problem, subject could formulate general premise and mention the premises which were used to solve the given problem. Subject could also formulate specific premise by giving logical premise referring to general premise based given problem, and he could draw conclusion by determining the strategy firstly to solve the given problem. At the executing planning phase for solving the problem, subject could formulate general premise using premises in order to solve the given problem. Subject could also formulate specific premise by determining logical premise referring to general premise based given problem, and he could draw conclusion using general and specific premise that had been proved. (2) Deductive reasoning e of the female student; at the planning phase for solving problem, subject could formulate general premise by mentioning the premises which were used to solve the given problem. Subject could also formulate specific premise by giving logical premise referring to general premise based given problem, and he could draw conclusion by determining the strategy firstly to solve the given problem. At the executing planning phase for solving the problem, subject could formulate general premise using premises which were used to solve the given problem. Moreover, subject could not formulate specific premises and the way he drew the conclusion was contradictive to the strategy he determined at the planning phase for solving problem.

Keyword: Deductive Reasoning, Solving Geometry Problem, Gender Difference

\section{PENDAHULUAN}

Menurut Depdiknas (2006) menyatakan bahwa tujuan diberikan pelajaran matematika di sekolah tingkat SMP adalah menggunakan penalaran pada pola dan sifat, melakukan manupulasi matematika dalam membuat generalisasi, menyusun bukti dan pernyataan matematika. Selain itu, dalam Kurikulum 2013 (Kemdikbud, 2013) juga menyatakan bahwa dalam kompetensi inti yang ke-4 terdapat penalaran, yaitu mengelola, menyaji, dan menalar dalam ranah konkret. Dengan demikian, penalaran merupakan unsur penting dalam proses pembelajaran matematika.

Hal ini juga didukung oleh beberapa pendapat ahli. Mueller \& Maher (2009: 34) mengatakan "Generally, researchers concur that reasoning and proof form the foundation of mathematical understanding and that learning to reason and justify is crucial for growth in mathematical knowledge" (Pada umumnya, para peneliti sepakat bahwa penalaran dan pembuktian membentuk landasan pemahaman matematika dan bahwa belajar untuk menalar dan membuktikan merupakan hal penting bagi perkembangan pengetahuan matematika). Selanjutnya, Ball \& Bass (2003: 28) mengatakan "mathematical understanding is meaningless without a serious emphasis on reasoning" (pemahaman matematika tidak memiliki makna tanpa penekanan penalaran yang serius).

Salah satu studi internasional untuk mengevaluasi pendidikan khusus untuk hasil belajar siswa yang berusia 14 tahun pada jenjang sekolah menengah pertama (SMP) yang diikuti oleh Indonesia adalah Trends in International Mathematics and ScienceStudy (TIMSS). Hasil studi TIMSS pada tahun 2011 menunjukkan bahwa kemampuan matematika siswa Indonesia berada pada level rendah khususnya pada kemampuan penalaran (dalam Rosnawati, 2013).

Hasil survei TIMMS tentang kemampuan matematika siswa Indonesia tidak jauh berbeda dengan hasil survei dari lembaga lain seperti PISA (Programme International for Student Assesment).

Pada tahun 2012 hasil survei PISA yang lalu terlihat bahwa, Indonesia berada di peringkat 
kedua terbawah untuk nilai matematika. Dari total 65 negara dan wilayah yang masuk survei PISA, Indonesia nomor ke-64 atau hanya lebih tinggi satu peringkat dari Peru. Survei PISA diikuti oleh negara-negara yang bergabung dalam The Organisation for Economic Cooperasinand Development (OECD)

http://nces.ed.Gov/pubs2014/2014024tables.pdf.

Menurut National Council of Teacher of Mathematics yang disingkat NCTM (2000) penalaran matematika dapat dicirikan sebagai salah satu bagian dari proses berpikir matematis. Salah satu tipe yang penting dalam penalaran matematika adalah penalaran deduktif. Penalaran deduktif adalah suatu proses penarikan kesimpulan dari hal-hal yang umum ke hal-hal yang khusus. Senada dengan hal tersebut, Agapay (1991:7) mengatakan "Deductive reasoning, therefore, is a process of going down to a particular specific truth on the basis of a universal truth" (penalaran deduktif merupakan proses menuju suatu kebenaran khusus yang dibangun dari suatu kebanaran umum).

Untuk mengetahui bagaimana penalaran deduktif seseorang khususnya seorang siswa dapat dilihat berdasarkan kemampuannya dalam menyelesaikan masalah matematika. Melalui kegiatan penyelesaian masalah matematika siswa dapat mengembangkan dan membangun ide-ide baru dari pengetahuan yang sudah dimiliki. Dengan menyelesaikan masalah matematika siswa akan memperoleh pengalaman menggunakan pengetahuan serta keterampilan yang telah dimiliki untuk diterapkan pada penyelesaian masalah yang bersifat tidak rutin. Masalah tersebut dapat dikategorikan dalam 2 tipe yaitu masalah menemukan dan masalah pembuktian.

Salah satu masalah matematika yang berkaitan dengan pembuktian, yaitu masalah geometri. Masalah geometri adalah situasi yang terkait dengan geometri yang disajikan dalam bentuk soal tidak rutin sehingga siswa tidak dapat segera menemukan cara penyelesaiannya.

Dalam hal ini, kaitannya dengan penalaran deduktif siswa dalam menyelesaikan masalah geometri dapat dikatakan berbeda-beda, salah satunya disebabkan oleh perbedaan gender. Sebagian para ahli berpendapat bahwa siswa perempuan lebih teliti dalam beberapa hal dibandingkan dengan siswa laki-laki. Hyde et all. (dalam Royer and Garofoli, 2005) melaporkan bahwa di sekolah dasar dan sekolah menengah skor tes matematika siswa perempuan cenderung lebih tinggi dari pada siswa laki-laki. Sedangkan Halpern dan LaMay (dalam Arends, 2008) mangatakan bahwa kebanyakan studi tidak menemukan perbedaan besar yang melekat pada anak laki-laki dan anak perempuan dalam hal kemampuan kognitif secara umum.

Santrock (2004) mengemukakan bahwa penalaran (reasoning) adalah pemikiran logis yang menggunakan logika induksi dan deduksi untuk menghasilkan kesimpulan. Hal ini berarti kesimpulan yang diperoleh dapat ditarik dari kasus-kasus yang bersifat khusus dan dapat juga sebaliknya, kesimpulan tersebut diperoleh dari hal yang bersifat umum.

Pernyataan serupa dikemukakan oleh Depdiknas (2006) bahwa penalaran merupakan suatu proses berpikir yang mengorganisasikan pengetahuan-pengetahuan untuk membuat sebuah kesimpulan. Pernyataan tersebut disimpulkan dari beberapa premis. Yang dimaksud dengan premis adalah data, bukti atau dasar yang menjamin terbentuknya kesimpulan. Adapun yang dimaksud dengan kesimpulan adalah pernyataan baru yang dihasilkan sesuai dengan premis-premis yang tersedia. Hal ini berarti bahwa tidak semua proses berpikir merupakan penalaran. Pertanyaan tersebut juga dipertegas dengan pendapat Copi dan Cohen (1994: 4) yang mengatakan "All reasoning is thinking, but not all thinking is reasoning" (semua penalaran merupakan pemikiran, tetapi tidak semua pemikiran merupakan penalaran). Hanya proses berpikir yang didasarkan pada data, bukti atau dasar pemikiran secara sistematis untuk mengambil kesimpulan yang merupakan penalaran.

Keraf (2007: 57) kata deduksi berasal dari kata Latin deducere (de yang berarti 'dari', dan kata ducere yang berarti 'menghantar', 'memimpin'). Dengan demikian, kata deduksi dapat diartikan sebagai "menghantar dari sesuatu ke sesuatu yang lain". Sebagai istilah dalam penalaran, deduksi merupakan suatu proses berpikir yang dimulai dari proposisi yang 
sudah ada, menuju kepada suatu proposisi baru yang berbentuk suatu kesimpulan. Suprianto (2013) menyatakan bahwa proposisi adalah pernyataan dalam bentuk kalimat yang merupakan rangkaian term (kata dalam kalimat) yang dapat dinilai benar dan salahnya. Dalam penelitian ini proposisi yang dijadikan dasar penyimpulan disebut dengan pernyataan umum atau pernyataan khusus serta hasil kesimpulannya disebut konklusi.

Sumaryono (1999) mengemukakan bahwa penalaran deduktif adalah penarikan kesimpulan yang bertolak dari hal-hal yang bersifat umum pada hal-hal yang bersifat khusus. Sedangkan menurut Warsono (2008: 90) "penalaran deduktif adalah penyimpulan yang konklusinya dimaksudkan sebagai penegasan apa yang sudah tersirat dalam premisnya". Hal ini berarti bahwa konklusinya sebagai keharusan logis dari premisnya, dan konklusinya pasti benar, jika semua premisnya benar.

Dalam kaitannya dengan proses pengambilan kesimpulan secara deduktif, menurut Rich \& Thomas (2009: 18) terdapat tiga langkah yaitu:

- Making a general statement referring to a whole set or class of things (Membuat pernyataan umum, yang mengacu pada keseluruhan himpunan atau klasifikasi benda).

- Making a particular statement about one or some of the members of the set or class referred to the general statement (Membuat pernyataan khusus tentang satu atau beberapa anggota himpunan atau klasifikasi yang mengacu pada pernyataan umum).

- Making a deduction that follows logically when the general statement is applied to the particular statement (Membuat deduksi yang dilakukan secara logis ketika pernyataan umum diterapkan pada pernyataan khusus).

Posamentier \& Krulik (2009: 2) menjelaskan "a problem is a situation that confronts the learner, that requires resolution, and for which the path to the answer is not immediately known" (masalah merupakan situasi yang dihadapi siswa, yang menghendaki penyelesaian dan jalan penyelesaiannya belum diketahui). Siswono (2008) menambahkan tentang kriteria suatu masalah adalah: (1) Individu menyadari/mengenali suatu situasi (pertanyaan- pertanyaan yang dihadapi). (2) Individu menyadari bahwa situasi tersebut memerlukan tindakan (aksi). (3) Langkah penyelesaian masalah tidak harus jelas atau mudah ditangkap orang lain.

Gestaltists (dalam Solso, 1995: 441) menyatakan bahwa "problems, especially perceptual problems, exist when tension or stress occurs as a result of some interaction between perception and memory. By thinking about a problem, or by examining it from different angles, the "correct" view can emerge in a moment of insight". Dengan kata lain, sesuatu itu dikatakanmasalah ketika ada kesenjangan yang terjadi sebagai akibat dari interaksi di dalam pikiran antara persepsi dengan memori yang sudah ada (pengetahuan awal). Penyelesaian dari masalah tersebut akan diperoleh sebagai hasil pikiran yang digabungkan dari berbagai sudut pandang.

Copeland (1976: 217) menyatakan, "Geometry is an important part of the mathematical experience of children of elementary school age. In fact, the first mathematical experiences of children as they explore objects in space are geometrical rather than arithmetical". Artinya Geometri merupakan bagian penting dari pengalaman matematika anak-anak usia sekolah dasar. Kenyataannya, pengalaman matematika pertama kali bagi anak-anak terjadi ketika mereka mengekplorasi objek-objek dalam ruang yang lebih bersifat geometri dari pada yang bersifat aritmatika.

\section{Gender}

Santrock (2003) mendefinisikan gender adalah dimensi sosial budaya seseorang sebagai laki-laki ataupun perempuan. Gender mempunyai peran sebagai suatu kumpulan harapan yang menetapkan bagaimana perempuan atau laki-laki harus berpikir, bertindak, dan berperasaan. Amir (2013) juga mendefinisikan gender adalah sifat dan perilaku yang dilekatkan pada laki-laki dan perempuan yang dibentuk secara sosial maupun budaya.

Menurut Sasongko (2009) gender adalah perbedaan peran, fungsi, dan tanggungjawab antara laki-laki dan perempuan yang merupakan hasil konstruksi sosial dan dapat berubah sesuai dengan perkembangan jaman. Sementara itu, 
Krutetski (dalam Nafi'an: 2011) menjelaskan bahwa ada perbedaan antara laki-laki dan perempuan dalam belajar matematika yaitu lakilaki lebih unggul dalam penalaran dan perempuan lebih unggul dalam ketepatan, ketelitian, kecermatan, dan keseksamaan berpikir. Selain itu, laki-laki memiliki kemampuan matematika dan mekanika yang lebih baik dari pada perempuan, perbedaan ini tidak tampak pada tingkat sekolah dasar akan tetapi menjadi tampak lebih jelas pada tingkat yang lebih tinggi.

Soemanto (2006: 157) juga memberikan pendapat bahwa "dari tes-tes yang pernah diberikan, wanita terutama berkelebihan dalam hal mengerjakan tes-tes yang menyangkut penggunaan bahasa, hafalan-hafalan, reaksireaksi estetika serta masalah-masalah sosial". Soemanto (2006) juga menambahkan bahwa laki-laki unggul dalam penalaran abstrak, penguasaan matematika dan mekanika.

\section{Hubungan Antara Penalaran Deduktif dan Gender}

Berdasarkan uraian di atas, peneliti menduga adanya hubungan antara penalaran deduktif dan gender karena penalaran deduktif merupakan aktivitas berpikir. Hal ini sejalan dengan apa yang diungkapkan Santrock (2003) tentang peran gender yaitu suatu kumpulan harapan yang menetapkan bagaimana perempuan atau laki-laki harus berpikir, bertindak, dan berperasaan.

Dalam aktivitas berpikir yang digunakan manusia untuk berpikir adalah otak, dimana otak tersebut memiliki perbedaan antara otak laki-laki dan otak perempuan. Seperti yang telah dijelaskan oleh Michel Gurian (dalam Arends, 2008) yang mengatakan bahwa perbedaan antara anak laki-laki dan perempuan memang ada akibat perbedaan dalam otak mereka. Sedangkan Kartini Kartono (dalam Asmaningtias: 2012) berpendapat bahwa betapapun baik dan cemerlangnya intelegensi perempuan, pada intinya perempuan hampirhampir tidak pernah mempunyai ketertarikan yang menyeluruh pada soal-soal teoritis seperti laki-laki, perempuan lebih tertarik pada hal-hal yang praktis dari pada teoritis, perempuan juga lebih dekat pada masalah masalah kehidupan praktis yang konkret, sedangkan laki-laki lebih tertarik pada segi-segi yang abstrak.

Berdasarkan pendapat-pendapat di atas dapat ditarik suatu kesimpulan bahwa ada hubungan antara penalaran deduktif dan gender dan juga ada perbedaan antara laki-laki dan perempuan dalam belajar matematika yaitu laki-laki lebih unggul dalam penalaran, perempuan lebih unggul dalam ketepatan, ketelitian, kecermatan, dan keseksamaan berpikir.

\section{METODE}

Penelitian ini termasuk dalam jenis penelitian deskriptif dengan pendekatan kualitatif. Hal ini dikarenakan dalam penelitian ini mempunyai tujuan untuk mendeskripsikan suatu keadaan atau fenomena-fenomena yang terjadi apa adanya (secara alami).

Subjek dalam penelitian ini adalah siswa kelas VIII SMP. Di pilih siswa kelas VIII SMP dengan pertimbangan bahwa siswa tersebut telah mendapatkan materi garis, sudut, dan segitiga di kelas VII semester 2 bab terakhir, sehingga memungkinkan untuk mendapatkan data yang lebih akurat dan tidak bias. Proses pemilihan subjek pada awalnya memilih satu kelas dari kelas VIII yang ada dengan bantuan guru matematika, kemudian calon subjek diberi tes kemampuan matematika yang diadopsi dari soal-soal Ujian Nasional (UN) SMP/MTs dari tahun 2011 sampai 2014. Soal tersebut menyesuaikan dengan materi yang telah dipelajari oleh siswa pada kelas VII dan VIII semester 1.

Selanjutnya dianalisis hasil tes kemampuan matematikanya dan subjek yang akan diambil yaitu subjek laki-laki dan subjek perempuan yang memiliki kemampuan matematika yang relatif sama. Kemampuan matematika kedua subjek dikatakan relatif sama jika subjek mempunyai rentang nilai tidak lebih dari atau sama dengan 5. Alasan memilih rentang nilai kemampuan matematika tidak lebih dari atau sama dengan 5 karena, semakin kecil rentang yang dipilih maka akan semakin bagus untuk dijadikan subjek penelitian. Hal ini juga didukung oleh pendapat Heris dan Utari (2014) bahwa dalam penilaian matematika, evaluator dapat menentukan kriteria sendiri sesuai yang diinginkan. Selain kemampuan matematika 
yang relatif sama, subjek tersebut harus mampu mengkomunikasikan pendapat atau jalan pikirannya secara lisan maupun tulisan dan bersedia di jadikan subjek penelitian. Dengan kata lain, pemilihan subjek didasarkan pada tiga kriteria, yaitu: (1) memiliki kemampuan matematika yang relatif sama; (2) dapat diajak berkomunikasi dengan baik; (3) bersedia untuk dijadikan subjek penelitian. Dengan menggunakan kriteria penilaian tersebut, maka akan di dapat 2 siswa yang dijadikan subjek dalam penelitian ini yaitu satu siswa laki-laki dan satu siswa perempuan.

Dalam penelitian ini teknik pengumpulan dilakukan dengan menggunakan dua teknik yaitu tes/tugas dan wawancara yang masingmasing diuraikan sebagai berikut:

\section{- Tes/tugas}

Dalam penelitian ini tes yang digunakan adalah tes kemampuan matematika dan tugas penyelesaian masalah geometri. Tes kemampuan matematika digunakan untuk pemilihan subjek penelitian yaitu dengan memilih subjek yang mempunyai kemampuan matematika yang relatif sama. Sedangkan tugas penyelesaian masalah geometri digunakan untuk mendapatkan data tentang penalaran deduktif siswa dalam menyelesaikan masalah geometri berdasarkan perbedaan gender.

\section{- Wawancara}

Setelah subjek dapat ditentukan, maka selanjutnya dilakukan wawancara terhadap setiap subjek. Wawancara pada penelitian ini menggunakan wawancara tidak terstruktur yaitu yang hanya memuat garis besar yang akan ditanyakan. Jadi pertanyaan-pertanyaan yang lain diajukan dan dikembangkan dalam pelaksanaan wawancara dan bergantung pada kondisi proses dan hasil penyelesaian masalah yang dikerjakan oleh siswa.

Dalam proses wawancara peneliti akan terus menggali informasi sehingga didapatkan data yang valid. Agar tidak ada informasi yang terlewat dan data yang diperoleh dijamin keabsahannya, maka dalam wawancara direkam dengan menggunakan handphone sebagai bahan dokumentasi peneliti untuk keperluan analisis data.
Analisis data dalam penelitian ini meliputi data hasil tes penentuan subjek penelitian, data hasil tugas penyelesaian masalah geometri dan data hasil wawancara pada subjek penelitian. Secara rinci tahapan analisis data diuraikan sebagai berikut:

\section{- Data penentuan subjek}

Penentuan subjek dalam penelitian ini menggunakan TKM. Peneliti menganalisis hasil TKM kemudian mengelompokkan siswa berdasarkan gender dan dilanjutkan dengan mengurutkan dari skor TKM yang terbesar ke skor TKM yang terkecil. Hal ini dimaksudkan untuk mempermudah peneliti dalam menentukan skor siswa laki-laki dan skor siswa perempuan yang memiliki kemampuan matematika yang ralatif sama. Kemampuan matematika kedua subjek dikatakan relatif sama jika kedua subjek tersebut mempunyai rentang nilai tidak lebih dari atau sama dengan 5 .

\section{- Data penyelesaian masalah geometri dan wawancara}

Data hasil tugas penyelesaian masalah geometri dan data hasil wawancara dianalisis dengan pendekatan kualitatif. Analisis data dalam penelitian ini mengacu pada beberapa tahapan, yaitu reduksi data, penyajian data, dan penarikan kesimpulan. Proses analisis data yang dilakukan dalam penelitian ini dilakukan dengan langkah-langkah sebagai berikut:

$\checkmark$ Reduksi data

$\checkmark$ Penyajian data

$\checkmark$ Penarikan kesimpulan

\section{HASIL DAN PEMBAHASAN \\ Subjek Laki-laki (SL)}

- Merencanakan Penyelesaian Masalah

SL merumuskan pernyataan umum dengan menyebutkan pernyataan yang digunakan untuk menjawab soal yang diberikan. Yaitu untuk soal nomor 1 SL menyebutkan pernyataan (Definisi) sudut berpelurus yang besarnya 180 derajat. Sedangkan untuk soal nomor 2 SL menyebutkan ada tiga pernyataan (Teorema dan Definisi) yaitu sudut yang sehadap besarnya sama, sudut yang dalam 
berseberangan besarnya sama dan sudut yang berpelurus besarnya 180 derajat.

SL merumuskan pernyataan khusus dengan menyebutkan pernyataan logis yang mengacu pada pernyataan umum berdasarkan soal yang diberikan. Yaitu untuk soal nomor 1 SL menyebutkan pernyataan (Definisi) sudut secara berpasang-pasangan, sudutsudut tersebut merupakan sudut berpelurus dan pernyataan yang telah disebutkan mengacu pada pernyataan sebelumnya. Sedangkan untuk soal nomor 2 SL menyebutkan pernyataan (Teorema dan Definisi) sudut-sudut yang sehadap dan sudut-sudut yang dalam dan sudut-sudut yang berpelurus dan pernyataan tersebut juga mengacu pada pernyataan sebelumnya.

SL melakukan penarikan kesimpulan dengan menetapkan strategi untuk menjawab soal yang diberikan. Yaitu untuk soal nomor 1 SL menetapkan strateginya dengan menggunakan sudut yang berpelurus besarnya 180 derajat (Definisi) dan SL tidak perlu menggambar ulang. Sedangkan untuk soal nomor 2 SL menetapkan strateginya dengan menggunakan sudut yang sehadap besarnya sama, sudut yang dalam berseberangan besarnya sama dan sudut yang berpelurus besarnya 180 derajat (Teorema dan Definisi) dan SL perlu menggambar ulang.

\section{- Melaksanakan Rencana Penyelesaian Masalah}

SL merumuskan pernyataan umum dengan menggunakan pernyataan yang digunakan untuk menjawab soal yang diberikan. Yaitu untuk soal nomor 1 SL membuat sudut berpelurus yang besarnya 180 derajat (Definisi). Sedangkan untuk soal nomor 2 SL membuat sudut sehadap yang besarnya sama, sudut dalam berseberangan yang besarnya sama dan sudut berpelurus yang besarnya 180 derajat (Teorema dan Definisi).

SL merumuskan pernyataan khusus dengan menetapkan pernyataan logis yang mengacu pada pernyataan umum berdasarkan soal yang diberikan. Yaitu untuk soal nomor 1 SL memasangkan sudut-sudut yang berpelurus yang besarnya 180 derajat (Definisi). Sedangkan untuk soal nomor $2 \mathrm{SL}$ memperoleh sudut-sudut yang sehadap besarnya sama, sudut-sudut yang dalam berseberangan besarnya sama dan sudutsudut yang berpelurus besarnya 180 derajat (Teorema dan Definisi).

SL melakukan penarikan kesimpulan dengan menggunakan premis-premis (pernyataan umum dan khusus) yang telah terbukti kebenarannya. Yaitu untuk soal nomor $1 \mathrm{SL}$ menyelesaikan soal dengan menggunakan sudut berpelurus yang besarnya 180 derajat (Definisi). Sedangkan untuk soal nomor 2 SL menyelesaikan soal dengan menggunakan sudut yang sehadap besarnya sama, sudut yang dalam berseberangan besarnya sama dan sudut yang berpelurus besarnya 180 derajat (Teorema dan Definisi).

\section{Subjek Perempuan (SP)}

\section{- Merencanakan Penyelesaian Masalah}

SP merumuskan pernyataan umum dengan menyebutkan pernyataan yang digunakan untuk menjawab soal yang diberikan. Yaitu untuk TPMG-1, soal nomor 1 SP menyebutkan pernyataan (Teorema) bahwa sudut yang berhadapan besarnya sama dan untuk TPMG-2, soal nomor 1 SP menyebutkan pernyataan (Teorema) bahwa sudut yang berseberangan dalam besarnya sama. Sedangkan untuk TPMG-1, soal nomor 2 SP menyebutkan pernyataan (Teorema dan Definisi) umum yaitu sudut yang berseberangan besarnya sama dan sudut yang berpelurus besarnya 180 derajat dan untuk TPMG-2, soal nomor 2 SP menyebutkan pernyataan umum (Teorema) yaitu sudut yang berseberangan besarnya sama dan sudut yang sehadap besarnya sama.

SP merumuskan pernyataan khusus dengan menyebutkan pernyataan logis yang mengacu/mengarah pada pernyataan umum berdasarkan soal yang diberikan. Yaitu untuk TPMG-1, soal nomor 1 SP menyebutkan pernyataan (Teorema) bahwa sudut secara berpasang-pasangan, sudut-sudut tersebut merupakan sudut yang saling berhadapan dan pernyataan yang telah disebutkan mengacu 
pada pernyataan sebelumnya dan untuk TPMG-2, soal nomor 1 SP menyebutkan pernyataan (Teorema) bahwa sudut-sudut secara berpasang-pasangan dan sudut tersebut merupakan sudut yang saling berseberangan dan SP menyebutkan bahwa pernyataan tersebut berdasarkan/mengacu pada pernyataan sebelumnya. Sedangkan untuk TPMG-1, soal nomor 2 SP menyebutkan pernyataan (Teorema dan Definisi) bahwa sudut-sudut secara berpasangan-pasangan yaitu sudut yang berseberangan besarnya sama dan sudut yang berpelurus besarnya 180 derajat dan pernyataan tersebut mengacu pada pernyataan sebelumnya dan TPMG-2, soal nomor 2 SP menyebutkan pernyataan (Teorema) bahwa sudut yang berseberangan besarnya sama dan sudut yang sehadap besarnya sama dan pernyataan tersebut mengacu pada pernyataan sebelumnya.

SP melakukan penarikan kesimpulan dengan menetapkan strategi untuk menjawab soal yang diberikan. Yaitu untuk TPMG-1, soal nomor 1 SP menetapkan strateginya dengan menggunakan sudut sehadap dan SP perlu menggambar ulang dan untuk TPMG2, soal nomor 1 SP menetapkan strateginya dengan menggunakan sudut yang berseberangan dan SP perlu menggambar ulang. Sedangkan untuk TPMG-1, soal nomor 2 SP menetapkan strateginya dengan menggunakan sudut berseberangan, sudut berpelurus dan SP perlu menggambar ulang dan untuk TPMG-2, soal nomor 2 SP menetapkan strateginya dengan menggunakan sudut berseberangan, sudut sehadap dan SP perlu menggambar ulang.

\section{- Melaksanakan Rencana Penyelesaian Masalah}

SP merumuskan pernyataan umum dengan menetapkan pernyataan yang digunakan untuk menjawab soal yang diberikan. Yaitu untuk TPMG-1, soal nomor 1 SP tidak mengkontruksi gambarnya dan menetapkan pernyataan (Teorema) sudut sehadap yang besarnya sama dan untuk TPMG-2, soal nomor 1 SP juga tidak mengkontruksi gambarnya dan menetapkan pernyataan (Teorema) sudut berseberangan yang besarnya sama. Sedangkan untuk TPMG-1, soal nomor 2 SP menambahi gambar dengan garis sejajar dan menetapkan pernyataan (Teorema dan Definisi) sudut yang berseberangan yang besarnya sama dan sudut berpelurus yang besarnya 180 derajat dan untuk TPMG-2, soal nomor 2 SP menambahi gambar dengan garis sejajar dan menetapkan pernyataan (Teorema) sudut yang berseberangan dan sudut yang sehadap yang masing-masing mempunyai besar yang sama.

Dalam merumuskan pernyataan khusus yaitu menetapkan pernyataan logis yang mengacu pada pernyataan umum berdasarkan soal yang diberikan. Yaitu untuk TPMG-1 dan TPMG-2, soal nomor 1 SP tidak memberikan alasan yang jelas tentang jawabannya. Sedangkan untuk TPMG-1, soal nomor 2 SP menambahi gambar dengan cara menambahi garis yang sejajar dan SP menetapkan pernyataan (Teorema dan Definisi) sudutsudut yang berseberangan yang besarnya sama dan sudut-sudut yang berpelurus yang besarnya 180 derajat dan untuk TPMG-2, soal nomor 2 SP menambahi gambar dengan cara menambahi garis yang sejajar dan SP menetapkan pernyataan (Teorema) sudut-sudut yang berseberangan yang besarnya sama dan sudut-sudut sehadap yang besarnya sama.

Dalam melakukan penarikan kesimpulan yaitu menggunakan premispremis (pernyataan umum dan khusus) yang telah terbukti kebenarannya. Yaitu untuk TPMG-1, soal nomor 1 SP menyelesaikan soal dengan menggunakan sudut sehadap yang besarnya sama dan untuk TPMG-2, soal nomor 1 SP menyelesaikan soal dengan menggunakan sudut dalam berseberangan. Sedangkan untuk TPMG-1, soal nomor 2 SP menyelesaikan soal dengan menggunakan sudut berseberangan dan untuk TPMG-2, soal nomor 2 SP menyelesaikan soal dengan menggunakan sudut berseberangan dan sudut sehadap, tapi 
TPMG-1 maupun TPMG-2, SP tidak dapat menyimpulkan jawabannya.

Penalaran Deduktif Subjek Laki-Laki dalam Menyelesaikan Masalah Geometri

Pada TPMG 1, subjek memenuhi semua indikator penalaran deduktif, yaitu merumuskan pernyataan umum, merumuskan pernyataan khusus, dan melakukan penarikan kesimpulan dalam menyelesaikan masalah geometri pada langkah merencanakan penyelesaian masalah dan melaksanakan rencana penyelesaian masalah. Untuk lebih jelasnya diuraikan sebagai berikut:

Pertama, Pada langkah merencanakan penyelesaian masalah, subjek telah dapat merumuskan pernyataan umum dengan menyebutkan pernyataan (aksioma, definisi, teorema) yang digunakan untuk menjawaban soal yang diberikan. Untuk soal nomor 1, subjek menyebutkan pernyataan (Definisi) sudut berpelurus yang besarnya 180 derajat sebagai pernyataan umumnya. Sedangkan soal nomor 2, subjek menyebutkan ada tiga pernyataan (Teorema dan Definisi) yaitu sudut yang sehadap besarnya sama, sudut yang dalam berseberangan besarnya sama dan sudut yang berpelurus besarnya 180 derajat sebagai pernyataan umumnya.

Subjek juga dapat merumuskan pernyataan khusus dengan menyebutkan pernyataan logis yang mengacu pada pernyataan umum (aksioma, definisi, teorema) berdasarkan soal yang diberikan. Untuk soal nomor 1, subjek menyebutkan pernyataan (Definisi) lebih rinci tentang sudut berpelurus, yaitu dengan menyebutkan sudut-sudut secara berpasangpasangan yang merupakan sudut berpelurus yang besarnya 180 derajat dan pernyataan yang telah disebutkan mengacu pada pernyataan umum. Sebagai contoh subjek menyebutkan sudut 2 dan sudut 3 , sudut 6 dan sudut 7 , sudut 2 dan sudut 1 yang masing-masing pasangan sudut tersebut merupakan sudut yang berpelurus. Untuk soal nomor 2, subjek dapat menyebutkan pernyataan (Teorema dan Definisi) lebih rinci tentang sudut sehadap, sudut berseberangan dan sudut berpelurus, yaitu dengan menyebutkan sudut yang sehadap besarnya sama dan sudut yang dalam berseberangan besarnya sama sedangkan sudut yang berpelurus besarnya 180 derajat dan pernyataan yang telah disebutkan mengacu pada pernyataan umum. Sebagai contoh subjek menyebutkan sudut $x$ dan sudut $g$ merupakan sudut yang sehadap, sudut $z$ dan sudut $f$ merupakan sudut yang dalam berseberangan dan sudut $y$, sudut $f$, dan sudut $g$ merupakan sudut yang berpelurus.

Selanjutnya, subjek dapat melakukan penarikan kesimpulan dengan menetapkan strategi untuk menjawab soal yang diberikan. Untuk soal nomor 1, subjek menetapkan strateginya dengan menggunakan sudut berpelurus dan subjek tidak perlu menggambar ulang. Sedangkan untuk soal nomor 2 subjek menetapkan strateginya dengan menggunakan sudut sehadap, sudut dalam berseberangan dan sudut berpelurus dan subjek perlu menggambar ulang.

Kedua, pada langkah melaksanakan rencana penyelesaian masalah, subjek dapat merumuskan pernyataan umum dengan menetapkan pernyataan (aksioma, definisi, teorema) yang digunakan untuk menjawab soal yang diberikan. Untuk soal nomor 1, subjek membuat sudut berpelurus yang besarnya 180 derajat (Definisi) untuk menjawab soal yang diberikan. Pernyataan tersebut sesuai dengan pernyataan yang disebutkan subjek pada saat merencanakan penyelesaian masalah. Sedangkan untuk soal nomor 2, subjek membuat sudut yang sehadap besarnya sama, sudut yang dalam berseberangan besarnya sama dan sudut yang berpelurus besarnya 180 derajat (Teorema dan Definisi). Pernyataan tersebut sesuai dengan pernyataan yang disebutkan subjek pada saat merencanakan penyelesaian masalah.

Subjek dapat merumuskan pernyataan khusus dengan menetapkan pernyataan logis yang mengacu pada pernyataan umum (aksioma, definisi, teorema) berdasarkan soal yang diberikan. Untuk soal nomor 1, subjek dapat memasangkan sudut-sudut yang berpelurus besarnya 180 derajat (Definisi). Pernyataan tersebut sesuai dengan pernyataan yang disebutkan subjek pada saat merencanakan penyelesaian masalah. Sedangkan untuk soal nomor 2, subjek dapat memperoleh sudut-sudut yang saling berhadapan besarnya sama, sudutsudut yang saling dalam berseberangan 
besarnya sama dan sudut-sudut yang berpelurus besarnya 180 derajat (Teorema dan Definisi). Pernyataan tersebut sesuai juga dengan pernyataan yang disebutkan subjek pada saat merencanakan penyelesaian masalah.

Selanjutnya, subjek dapat melakukan penarikan kesimpulan dengan menggunakan premis-premis (pernyataan umum dan khusus) yang telah terbukti kebenarannya. Hal ini sesuai dengan pendapat Warsono (2008) yang mengatakan penalaran deduktif merupakan penyimpulan yang konklusinya dimaksudkan sebagai penegasan apa yang sudah tersirat dalam premisnya. Untuk soal nomor 1, subjek menyelesaikannya dengan menggunakan sudut berpelurus yang besarnya 180 derajat. Pernyatan tersebut sesuai dengan pernyataan yang disebutkan subjek pada saat menetapkan starteginya untuk menjawab soal yang diberikan. Sedangkan untuk soal nomor 2, subjek menyelesaikannya dengan menggunakan sudut yang sehadap besarnya sama, sudut yang dalam berseberangan besarnya sama dan sudut yang berpelurus besarnya 180 derajat. Pernyatan tersebut juga sesuai dengan pernyataan yang disebutkan subjek pada saat menetapkan starteginya untuk menjawab soal yang diberikan.

\section{Penalaran Deduktif Subjek Perempuan dalam Menyelesaikan Masalah Geometri}

Pada TPMG 1, subjek tidak memenuhi semua indikator penalaran deduktif, yaitu pada langkah melaksanakan rencana penyelesaian masalah. Sedangkan pada langkah merencanakan penyelesaian masalah subjek memenuhi semua indikator penalaran deduktif, yaitu merumuskan pernyataan umum, merumuskan pernyataan khusus, dan melakukan penarikan kesimpulan. Untuk lebih jelasnya diuraikan sebagai berikut:

Pertama, pada langkah merencanakan penyelesaian masalah, subjek dapat merumuskan pernyataan umum dengan menyebutkan pernyataan (aksioma, definisi, teorema) yang digunakan untuk menjawaban soal yang diberikan. Untuk soal nomor 1, subjek menyebutkan pernyataan (Teorema) sudut yang berhadapan besarnya sama sebagai pernyataan umumnya. Sedangkan soal nomor 2, subjek menyebutkan ada dua pernyataan (Teorema dan
Definisi) yaitu sudut yang dalam berseberangan besarnya sama dan sudut yang berpelurus besarnya 180 derajat sebagai pernyataan umumnya.

Subjek dapat merumuskan pernyataan khusus dengan menyebutkan pernyataan logis yang mengacu pada pernyataan umum (aksioma, definisi, teorema) berdasarkan soal yang diberikan. Untuk soal nomor 1, subjek menyebutkan pernyataan (Teorema) lebih rinci tentang sudut sehadap yaitu dengan menyebutkan sudut-sudut secara berpasangpasangan dan pernyataan yang telah disebutkan mengacu pada pernyataan umum. Sebagai contoh, sudut 2 dan sudut 6 saling berhadapan, sudut 3 dan sudut 7 saling berhadapan. Sedangkan soal nomor 2, subjek menyebutkan pernyataan (Teorema dan Definisi) lebih rinci tentang sudut berseberangan dan sudut berpelurus, yaitu dengan menyebutkan sudutsudut yang dalam berseberangan besarnya sama dan sudut-sudut yang berpelurus besarnya 180 derajat dan pernyataan yang telah disebutkan mengacu pada pernyataan umum. Sebagai contoh, sudut $a$ dan sudut $d$ merupakan sudut yang dalam berseberangan, sudut $d$, sudut $b$, dan sudut $e$ merupakan sudut yang berpelurus.

Selanjutnya, subjek dapat melakukan penarikan kesimpulan dengan menetapkan strategi untuk menjawab soal yang diberikan. Untuk soal nomor 1, subjek menetapkan strateginya dengan menggunakan sudut sehadap dan subjek perlu menggambar ulang. Sedangkan untuk soal nomor 2 subjek menetapkan strateginya dengan menggunakan sudut dalam berseberangan dan sudut berpelurus dan subjek juga perlu menggambar ulang.

Kedua, pada langkah melaksanakan rencana penyelesaian masalah, subjek dapat merumuskan pernyataan umum dengan menggunakan pernyataan (aksioma, definisi, teorema) yang digunakan untuk menjawab soal yang diberikan. Untuk soal nomor 1, subjek membuat sudut sehadap yang besarnya sama (Teorema) untuk menjawab soal yang diberikan. Pernyataan tersebut sesuai dengan pernyataan yang disebutkan subjek pada saat merencanakan penyelesaian masalah dan subjek tidak mengkontruksi gambar yang ada pada soal, hanya digambar ulang saja. Sedangkan nomor 2, 
subjek membuat sudut yang dalam berseberangan besarnya sama dan sudut yang berpelurus besarnya 180 derajat (Teorema dan Definisi). Pernyataan tersebut sesuai dengan pernyataan yang disebutkan subjek pada saat merencanakan penyelesaian masalah dan subjek mengkontruksi gambar yang ada pada soal.

Dalam merumuskan pernyataan khusus dengan menetapkan pernyataan logis yang mengacu pada pernyataan umum (aksioma, definisi, teorema) berdasarkan soal yang diberikan. Untuk soal nomor 1, subjek tidak memberikan alasan yang jelas tentang jawabannya, sehingga dalam hal ini subjek tidak memenuhi indikator dalam merumuskan pernyataan khusus. Sedangkan untuk soal nomor 2, subjek dapat memperoleh sudut-sudut yang saling dalam berseberangan besarnya sama dan sudut-sudut yang berpelurus besarnya 180 derajat (Teorema dan Definisi). Pernyataan tersebut juga sesuai dengan pernyataan yang disebutkan subjek pada saat merencanakan penyelesaian masalah dan subjek mengkontruksi gambar di soal dengan cara menambahi garis yang sejajar. Hal ini berarti bahwa subjek telah memenuhi indikator dalam merumuskan pernyataan khusus untuk melaksanakan rencana penyelesaian masalah pada soal nomor 2 .

Selanjutnya, dalam melakukan penarikan kesimpulan dengan menggunakan premispremis (pernyataan umum dan khusus) yang telah terbukti kebenarannya. Hal ini sesuai dengan pendapat Warsono (2008) yang mengatakan penalaran deduktif merupakan penyimpulan yang konklusinya dimaksudkan sebagai penegasan apa yang sudah tersirat dalam premisnya. Untuk soal nomor 1, subjek menyelesaikannya dengan menggunakan sudut sehadap yang besarnya sama. Pernyatan tersebut sesuai dengan pernyataan yang disebutkan subjek pada saat menetapkan starteginya untuk menjawab soal yang diberikan. Hal ini berarti subjek telah memenuhi indikator dalam melakukan penarikan kesimpulan untuk melaksanakan rencana penyelesaian masalah pada soal nomor 1. Sedangkan untuk soal nomor 2, subjek menyelesaikannya dengan menggunakan sudut yang berseberangan besarnya sama. Pernyatan tersebut tidak sesuai dengan pernyataan yang disebutkan subjek pada saat menetapkan starteginya untuk menjawab soal yang diberikan. Karena pada saat menetapkan strateginya subjek menyebutkan juga sudut berpelurus yang besarnya 180 derajat dan subjek tidak dapat menyimpulkan jawabannya. Hal ini berarti bahwa subjek tidak memenuhi semua indikator dalam melakukan penarikan kesimpulan untuk melaksanakan rencana penyelesaian masalah pada soal nomor 2.

\section{SIMPULAN DAN SARAN \\ Simpulan}

\section{- Subjek Laki-laki}

Dalam menyelesaikan masalah geometri, subjek merumuskan pernyataan umum dengan menyebutkan pernyataan yang berkaitan dengan apa yang akan dibuktikan serta dapat menggunakannya dalam menjawab soal yang diberikan. Yaitu untuk nomor 1, subjek dapat menyebutkan sudut berpelurus yang besarnya 180 derajat sedangkan untuk nomor 2, subjek dapat menyebutkan sudut yang sehadap besarnya sama, sudut yang berseberangan besarnya sama dan sudut yang berpelurus besarnya 180 derajat.

Dalam merumuskan pernyataan khusus, subjek dapat menyebutkan pernyataan logis yang mengacu pada pernyataan umum. Oleh karena itu terdapat saling keterkaitan di antara kedua pernyataan tersebut. Subjek menetapkan pernyataan khusus dengan menuliskannya dilembar jawabannya.

Selanjutnya dalam melakukan penarikan kesimpulan, subjek menggunakan stategi untuk menyelesaikan masalah yaitu dengan menggunakan pernyataan yang disebutkan pada pernyataan umumnya. Yaitu untuk soal nomor 1, subjek menggunakan sudut berpelurus yang besarnya 180 derajat untuk menjawabnya. Sedangkan untuk soal nomor 2, subjek menggunakan sudut yang sehadap besarnya sama, sudut yang berseberangan besarnya sama dan sudut yang berpelurus besarnya 180 derajat.

\section{- Subjek Perempuan}

Dalam menyelesaikan masalah geometri, subjek merumuskan pernyataan umum 
dengan menyebutkan pernyataan yang berkaitan dengan apa yang akan dibuktikan serta dapat menggunakannya dalam menjawab soal yang diberikan. Yaitu untuk nomor 1, subjek dapat menyebutkan sudut yang sehadap besarnya sama. Sedangkan untuk nomor 2, subjek dapat menyebutkan sudut yang berseberangan besarnya sama dan sudut yang berpelurus besarnya 180 derajat.

Dalam merumuskan pernyataan khusus, subjek tidak dapat menetapkan pernyataan khusus untuk soal yang nomor 1, subjek juga tidak memberikan alasan yang jelas tentang jawabannya. Sedangkan untuk soal nomor 2, subjek dapat menetapkan pernyataan khususnya yaitu dapat memperoleh sudutsudut yang saling dalam berseberangan besarnya sama dan sudut-sudut yang berpelurus besarnya 180 derajat.

Selanjutnya dalam melakukan penarikan kesimpulan, subjek menetapkan strategi dan menggunakan stategi tersebut untuk menyelesaikan masalah yaitu dengan menggunakan pernyataan yang disebutkan pada pernyataan umumnya. Untuk soal nomor 1, subjek menyelesaikannya dengan menggunakan sudut sehadap besarnya sama. Sedangkan untuk soal nomor 2, subjek menyelesaikannya dengan menggunakan sudut yang berseberangan besarnya sama, dalam hal ini subjek tidak menggunakan strategi sesuai dengan rencana. Karena pada saat menetapkan strateginya subjek menyebutkan juga sudut berpelurus yang besarnya 180 derajat.

\section{Saran}

- Hasil penelitian menunjukkan adanya perbedaan antara penalaran deduktif siswa laki-laki dan penalaran deduktif siswa perempuan SMP dalam menyelesaikan masalah geometri. Oleh karena itu, disarankan agar guru/pendidik hendaknya memperhatikan gender dalam proses pembelajaran terutama dalam bidang geometri.

- Peneliti lain yang ingin melakukan penelitian serupa terkait dengan penalaran deduktif hendaknya meneliti pada subjek selain berdasarkan gender bisa seperti gaya kognitif atau gaya belajar, dan materinya selain materi geometri.

- Subjek dalam penelitian ini masih kurang bervariatif dan luas, karena hanya terdiri dari 2 (dua) subjek dan kedua subjek tersebut siswa SMP. Oleh karena itu, peneliti menyarankan untuk dilakukan penelitian lanjutan yang lebih bervariatif terhadap siswa SD, SMA, dan Mahasiswa.

\section{DAFTAR PUSTAKA}

Agapay, Ramon B. (1991). Logic The Essentials of Deductive Reasoning. Quezon City: National Book Store.

Amir, Zubaidah MZ. (2013). "Perspektif Gender Dalam Pembelajaran Matematika". Jurnal Kajian Gender dan Islam. Vol 12 No. 1, pp. 14-31.

Arends, Richard I. (2008). Learning To Teach, Belajar untuk Mengajar. Edisi ketujuh. Yogyakarta: Pustaka Belajar.

Arifin, Zaenal. (2010). Membangun Kompetensi Pedagogis Guru Matematika Landasan Filosofi, Histori, dan Psikologi. Surabaya: Lentera Cendikia.

Asmaningtias, Yeni Tri. (2012). Kemampuan Matematika Laki-laki dan

Perempuan.ejournal.uinmalang.ac.id/index.php/tarbiyah/.../pdf.Diu nduh tanggal 5 Januari 2015

Ball, D. L., \& Bass, H. (2003). Making mathematical reasonable in school. In $\mathrm{J}$. Kilpatrick, W. G. Martin, and D. Schifer (Eds.), A Research Companion to Principles and Standards for School Mathematics (pp. 27-44). Reston, VA: National Council of Teacher of Mathematics.

Copeland, Richard W. (1976). Mathematics and The Elementary Teacher 3rd Edition. Philadelphia. London Torondo. Sauders, W B Company.

Depdiknas. 2006. Standar Kurikulum Tingkat Satuan Pendidikan Mata Pelajaran Matematika. Jakarta: Depdiknas.

Hendriana, Heris dan Soemarno, Utari. (2014). Penilaian Pembelajaran Matematika. Cimahi: PT. Refika Aditama.

Kemdikbud. (2013). Kurikulum 2013. Kompetensi Dasar Sekolah Menengah 
Pertama (SMP)/Madrasah Tsanawiyah (MTs). Jakarta: Kemdikbud.

Keraf, G. (2007). Argumentasi dan Narasi. Jakarta: PT Gramedia Pustaka Utama.

Mueller, Mary \& Maher, Carolyn. (2009). "Learning to reason in an informal math after-school program". Mathematics Education Research Journal Vol. 21, No.3, 7-35.

Nafi'an, Muhammad ilman. (2011). Kemampuan Siswa Dalam Menyelesaikan Soal Cerita Ditinjau dari Gender di Sekolah Dasar. Yogyakarta: Seminar Nasional Matematika dan Pendidikan Matematika. Yogyakarta 3 Desember 2011.

NCTM. (2000). Principles and Standards for School Mathematics. Reston: The National Council of Teachers of Mathematics, Inc.

PISA. (2012). National Center of Education Statistics; Average scores of 15-year-old students on PISA sciences literacy scale, by education system. (http://nces.ed.gov./pubs2014/2014024 tabl es.pdf). Diunduh, 26 Februari 2015. Pukul; 23:00 WIB.

Posamentier, Alfred S. \& Krulik Stephen. (2009). Problem Solving in Mathematics Grades 3-6. United State of America: Corwin.

Rich, Barnett \& Thomas, Christopher. (2009). Schaum's outlines Problem Solved. Geometry fourth Editioan. New York: The McGraw-Hill Companies, Inc.

Rosnawati, R. (2013). "Kemampuan Penalaran Matematika Siswa SMP Indonesia Pada TIMSS 2011". Prosiding Seminar Nasional Penelitian, Pendidikan dan Penerapan MIPA, Universitas Negeri Yogyakarta, tanggal 18 Mei 2013.

Royer, James M. dan Garofoli, Laura M. (2005). Cognitive contributions to sex differences in math performance. in gender defferences in mathematics an integrative psychological approach. Cambridge University Press.

Santrock, John W. (2003). Adolescense perkembangan remaja. Edisi Keenam. Alih Bahasa: Dra. Shinto B. Adelar, M.Sc. Jakarta: Erlangga.
Sasongko, Sri Sundari. (2009). Konsep dan teori gender. Pusat Pelatihan Gender dan Peningkatan Kualitas Perempuan, BKKBN

Siswono, Tatag Y.E. (2008). Model Pembelajaran Matematika Berbasis Pengajuan dan Pemecahan Masalah Untuk Meningkatkan Kemampuan Berpikir Kreatif. Surabaya. Unesa University Press.

Soemanto, Wasty. (2006). Psikologi Pendidikan (Landasan Kerja Pemimpin Pendidikan). Jakarta: Rineka Cipta.

Solso, Robert L. (1995). Cognitive psychology. Boston: Allyn and Bacon.

Sumaryono, E. (1999). Dasar-dasar logika. Yogyakarta: Kanisius.

Suriasumantri, Jujun S. (1988). Filsafat ilmu sebuah pengantar populer. Jakarta: Pustaka Sinar Harapan.

Supriyanto, Stefanus. (2013). Filsafat Ilmu. Jakarta: Prestasi Pustaka Publisher.

Warsono. (2008). Logika Cara Berfikir Sehat. Surabaya: Unesa University Press. 